\title{
Influence of pasture feeding on milk and meat products in terms of human health and product quality
}

\author{
C. Stanton ${ }^{1,2,3+}$, S. Mills ${ }^{2}$, A. Ryan ${ }^{2,4}$, D. Di Gioia ${ }^{5}$, R.P. Ross ${ }^{2}$ \\ ${ }^{1}$ Teagasc, Moorepark Food Research Centre, Fermoy, Co. Cork, Ireland \\ ${ }^{2}$ APC Microbiome Ireland, University College Cork, Cork, Ireland \\ ${ }^{3}$ Vistamilk SFI Research Centre, Teagasc, Moorepark, Fermoy, Co. Cork, Ireland \\ ${ }^{4}$ School of Food and Nutritional Sciences, University College Cork, Cork, Ireland \\ ${ }^{5}$ Department of Agriculture and Food Sciences, University of Bologna, Bologna, Italy
}

Abstract

Cows are fed either indoors on a diet of mixed ration or in areas with temperate climates, such as Ireland and New Zealand, the feeding regime of dairy and beef herds is almost entirely pasture-based. Animal feeding regimes and herd management practices are linked to differences in organoleptic and nutritional quality attributes of milk, dairy and meat/beef products, with pasture-based feeding systems being associated with superior quality produce. Consumers generally perceive that milk and meat products produced from outdoor grazing pastures are "healthier" than produce derived from indoor feeding systems, based on animals fed typical indoor rations and concentrates. However, while research has demonstrated differences in milk and meat quality, especially in terms of fatty acids, based on different feeding systems, data are limited on the impact of dairy and meat products produced from different feeding systems on human health.

Keywords

Beef $\cdot$ milk $\cdot$ nutritional quality $\cdot$ pasture-fed

\section{Introduction}

The composition of bovine milk and meat, in particular the fatty acid composition, can be significantly influenced by the feeding regime. In many regions of the world including the United States, the Middle East, Asia and parts of Europe, cows and cattle are fed indoors and receive a diet of grass/ maize (Zea mays L.)/alfalfa (Medicago sativa L.) silages supplemented with concentrates, known as total mixed ration (TMR). However, in Ireland and New Zealand, they are typically fed outdoors where they have access to fresh pasture, which is why there is a predominant seasonal calving regime and milk production system in both places. Pasture-based dairy and meat products are popular amongst consumers as they are positively associated by consumers with good animal welfare and more natural and healthier products (Verkerk, 2003). Specific feeding regimes and herd management practices such as pasture feeding are linked to superior organoleptic and nutritional quality attributes of milk, dairy and meat products (Mann et al., 2003; Haug et al., 2007). The aim of this review is to compare the nutritional quality of bovine milk, dairy and meat produce from pasture feeding with indoor feeding systems and summarise the current data with regard to human health impacts of dairy and beef from the different feeding systems.

\section{Nutritional quality of milk}

Milk and dairy products derived from it are among the most nutritious foods available for human nutrition, being excellent sources of high-quality protein and important sources of many minerals, notably dietary calcium, magnesium and phosphorus, vitamins (fat-soluble vitamins, A, D, E and K, and water-soluble vitamins, $\mathrm{B}$ and $\mathrm{C}$ ) and bioactive compounds. Bovine milk composition varies in response to animal genetics, nutrition and stage of lactation, but is generally composed of $5 \%$ lactose, $4 \%$ lipid, $3.2 \%$ protein and $0.7 \%$ mineral salts (Séverin \& Wenshui, 2005).

Bovine milk is an important source of dietary protein as it provides a source of all essential amino acids. The major proteins in milk include whey proteins $(6.3 \mathrm{~g} / \mathrm{L})$ and caseins 
(26 g/L) (Séverin \& Wenshui, 2005). A scoring system to describe dietary protein quality was proposed by the Food and Agricultural Organisation (FAO) of the United Nations in 2013, called the digestible indispensable amino acid score (DIAAS) (FAO, 2013), and dairy proteins have one of the highest DIAASs (Wolfe, 2015) (Table 1). Furthermore, milk proteins contain latent bioactive peptides encrypted within their amino acid sequences which are released upon proteolysis such as those that occur in the gastrointestinal tract. These bioactive peptides exhibit a range of biological activities including antihypertensive, antithrombotic, cytomodulatory, immunomodulatory and antimicrobial activity, as examples (Mills et al., 2011). However, allergy to the proteins in bovine milk can be a problem for some infants and children. The exact extent of this in the developed world is hard to determine, but is estimated at $2-3 \%$ in infants and is reduced to less than $1 \%$ by the age of 6 years (Edwards \& Younus, 2019).

The mineral composition of milk is dependent on stage of lactation, genetic factors and, to a lesser extent, animal

Table 1: Digestible indispensible amino acid score (DIAAS) of milk and other protein sources

\begin{tabular}{lcc}
\hline Food (NDB) & (1AAS & FAO proposed system \\
\hline Animal-derived foods & & \\
Milk, whole (01077) & 114 & Good source \\
Eggs, hard-boiled (01129) & 113 & Good source \\
Chicken breast (05064) & 108 & Excellent source \\
Cereal-based foods & & \\
Oatmeal (08121) & 84 & Good source \\
Wheat bread, white (20083) & 29 & No claim \\
Rice, white (20045) & 57 & No claim \\
Mixed dishes & & \\
Macaroni and cheese (36009) & 90 & Good source \\
Beef stew (22905) & 45 & No claim \\
Legume/pulse foods & & No claim \\
Baked beans (16006) & 56 & Good source \\
Chickpeas, boiled (16057) & 83 & No claim \\
Soy-based tofu (16426) & 52 &
\end{tabular}

Adapted from Marinangeli and House (2017)

${ }^{1} \mathrm{NDB}=$ Nutrient Database Number from the USDA Nutrient

Database USDA National Nutrient Database for Standard Reference:

Release 28. http://www.ars.usda.gov/Services/docs.htm?docid=8964 (accessed 12 August 2016)

${ }^{2}$ DIAAS calculated using available digestibility coefficients (ileal or faecal) or using estimates of 0.85

${ }^{3}$ Food and Agriculture Organization of the United Nations Food and Nutrition paper 92, chapter 4.1: The digestible indispensable amino acid score (DIAAS) (FAO, 2013) nutrition (Zamberlin, 2012). Mineral elements in milk and dairy products exist as inorganic ions and salts and as part of organic molecules including proteins, fats and carbohydrates. While milk is a source of all the essential minerals for human nutrition (Cashman, 2006), the most abundant minerals present in bovine milk are calcium and phosphorus, mostly associated with the casein micelle structure, and it is also a good source of magnesium and potassium. Animal diet does not significantly influence the content of these minerals in milk. Milk is a good source of some vitamins, notably the fat-soluble vitamins (found in the milk fat fraction), which are influenced by animal diet, with high levels reported in fresh grass. It was reported that milk produced in summer months in Finland was 3-4 times higher in vitamin $E$ than that produced in winter, as a result of feeding regime (Syvaoja et al., 1985). Milk is also a source of some watersoluble vitamins especially riboflavin (B2), thiamin (B1) and cobalamin (B12), which are derived from a combination of animal diet and the rumen microbiota and vary with the stage of lactation. It was reported that B12 concentration was six times higher in colostrum than in milk produced $39 \mathrm{~d}$ after calving, while folate concentration was nine times higher in colostrum (Duplessis et al., 2016).

More than $50 \%$ of the fatty acids in bovine milk are derived from the diet (Lindmark Månsson, 2008) and over $50 \%$ of milk fatty acid content is composed of saturated fatty acids (SFAs). While these fatty acids have received negative attention in terms of human health, more recent research suggests that the association between SFA intake and heart disease risk factors requires re-evaluation. Indeed, a meta-analysis of prospective epidemiologic studies evaluating the association between SFA intake and cardiovascular disease (CVD) in 2010 revealed that there was no significant evidence to conclude that dietary SFA was associated with an increased risk of coronary heart disease (CHD) or CVD (Siri-Tarino et al., 2010). In 2015, a meta-analysis of 22 studies revealed an inverse association between dairy consumption and overall risk of CVD and stroke (Qin et al., 2015). Several of the SFA found in milk have been shown to exhibit beneficial activities; butyric acid (C4:0) accounts for approximately $10 \%$ of all fatty acids in bovine milk (Jensen, 2002) and has been associated with anti-cancer properties (German, 1999), and lauric acid (C12:0) and capric acid (C10:0) were revealed to have antimicrobial properties (Petrone et al., 1998; Sprong et al., 2001,2002 ). It should also be stated at this point that milk of other species, including goats, are also good sources of beneficial fats (Barłowska et al., 2011). The long-chain SFA found in milk, stearic acid (C18:0), does not appear to raise serum cholesterol levels (Grundy, 1994). Bovine milk is also a source of monounsaturated fatty acids (MUFAs) and polyunsaturated fatty acids (PUFAs). The essential 
PUFAs, omega 3 (a-linolenic acid, 18:3n-3) and omega-6 (linoleic acid, 18:2n-6), which cannot be synthesised by any member of the Kingdom Animalia and must be acquired from the diet, occur in milk at levels between 0.5 and $2 \mathrm{wt} \%$ and between 1 and $3 \mathrm{wt} \%$, respectively (Jensen, 2002). As well as exhibiting numerous beneficial effects in vitro and in vivo (Connor, 2000; Dupertuis et al., 2007; Poulsen et al., 2007; Siddiqui et al., 2008), these fatty acids are converted to eicosanoids which play essential metabolic roles in the body. The Western diet has been associated with an increase in the intake of $n-6$ fatty acids resulting in a dietary n-3 to n- 6 fatty acid ratio of between 1:10 and 1:20 which is well above the desirable ratio of 1:1-4 (Molendi-Coste et al., 2011). However, the ratio of $n-3$ to $n-6$ fatty acids in milk is favourable compared to most other non-marine foods (Haug et al., 2007) and can be influenced via feeding regime, as discussed later. The bioactive conjugated linoleic acid (CLA) has been associated with numerous beneficial effects and has been shown to provide protection against cancer, diabetes, obesity and CVD based on in vitro and in vivo studies in animals (Yang et al., 2017). Bovine milk is a source of CLA, particularly the cis-9, trans-11 isomer (c9t11 CLA), which accounts for over $90 \%$ of total milk fat CLA (Stanton et al., 2003). It is produced as an intermediate product in the biohydrogenation of unsaturated fatty acids in the rumen, when dietary linoleic acid is converted to stearic acid by bacteria in the rumen and it can also be produced in the mammary gland from vaccenic acid $(C 18: 1, t 11)$ by the action of the enzyme delta9-desaturase (Kepler et al., 1966).

The fat in milk occurs as milk fat globules surrounded by the milk fat globule membrane (MFGM) which is composed primarily of cholesterol, phosphatidylcholine, glycolipids, glycoproteins, sphingomyelin and gangliosides (Ward et al., 2006). The MFGM is recognised for its antimicrobial activity (Sanchez-Juanes et al., 2009; Douëllou et al., 2017) and has been associated with numerous health benefits (Spitsberg, 2005; Mills et al., 2011). Most recently, a randomised clinical trial in humans revealed that milk fat delivered within an encapsulated MFGM structure does not impair the lipoprotein profile of humans in contrast to milk fat without a MFGM (Rosqvist et al., 2015).

Lactose, the major milk sugar, and its derivatives have received increasing attention in light of their prebiotic activities (Schaafsma, 2008). In this regard, it has been suggested that lactose be redefined as a "conditional prebiotic" (Szilagyi, 2004). However, lactose intolerance, which describes an impaired capacity to digest lactose, can be a problem for both infants and adults. Indeed, the ability to digest lactose beyond weaning is generally only maintained in descendants of populations which practise cattle domestication (Deng et al., 2015). In the case of lactose intolerance related to dairy foods, enzyme replacement and dietary changes can effectively treat the issue (Deng et al., 2015).

\section{Milk and dairy product quality from a pasture- based feeding system}

Life cycle assessment (LCA) is used to compare multiple livestock production systems in terms of environmental impact. McAuliffe et al. (2018) recently proposed a novel framework whereby the nutritional quality of meat should also be included in LCA. Interestingly, milk and dairy produce from pasture differ from those produced from TMR diets fed indoors. This was recently reported in a series of publications by Teagasc researchers as part of an ongoing research programme addressing the potential benefits of dairy produce from pasturebased systems compared to TMR systems. This work has already clearly shown benefits in terms of superior nutritional properties, appearance, colour and flavour of milk and dairy products including butter and cheese from pasture-fed dairy cattle (O'Callaghan et al., 2016a, 2016b, 2017). O'Callaghan et al. (2016a) investigated the impact of different feeding systems on milk composition and quality over an entire lactation. Feeding a perennial ryegrass (Lolium perenne L.) pasture or a perennial ryegrass/white clover (Trifolium repens $L$.) pasture resulted in milk with significantly higher concentrations of fat, protein, true protein, casein and whey compared to milk from cows fed TMR indoors. Moreover, milk of pasture-fed animals was two-fold higher in the c9t11 CLA content of milk, which as mentioned earlier has been associated with numerous beneficial health effects. In addition, pasture feeding resulted in milk with significantly increased n-3 PUFAs, significantly decreased $n-6$ PUFAs and, therefore, an improved $n-3 / n-6$ ratio compared to TMR-based milk. The TMR-derived milk had a significantly higher thrombogenic index compared to the pasture-derived milk. The thrombogenic index is an indicator of the tendency for clots to be formed in the blood vessels and a higher index is therefore undesirable.

Butters manufactured from milk produced on the perennial ryegrass pasture, perennial ryegrass/white clover pasture and TMR were significantly different in terms of quality characteristics, nutritional properties and consumer perception (O'Callaghan et al., 2016b). Butter produced from pasturefed cows was superior in appearance, flavour and colour as confirmed by sensory panel data. Unsurprisingly, the pasturederived butter revealed improved nutritional properties including lower thrombogenicity scores, higher c9t11 CLA and $\beta$-carotene concentrations. $\beta$-Carotene is a precursor of vitamin $A$ and carotenoids such as $\beta$-carotene exert several biological functions including antioxidant activities, tumour inhibition and induction of apoptosis (Milani et al., 2017). Feeding system also influenced the nutritional properties of full-fat Cheddar 
cheese (O'Callaghan et al., 2017). Pasture-derived cheese was yellower than its TMR-derived counterpart which was positively correlated with increased $\beta$-carotene content. Again, significantly lower thrombogenicity scores were reported for the pasture-derived cheese as well as two-fold higher levels of c9t11 CLA isomer and vaccenic acid, which is a precursor of CLA. The pasture-derived cheeses had significantly higher n-3 fatty acid contents, whereas the TMR-derived cheeses had significantly higher n-6 fatty acid contents.

Feeding system can significantly impact the technological properties of milk and dairy products, as has been well recognised in relation to the spreadability of butter (Wood et al., 1975; Banks \& Christie, 1990; Couvreur et al., 2006; Hurtaud \& Peyraud, 2007). We recently also reported similar findings in that significant differences were observed in the textural and thermal properties of butters manufactured from pasturederived and TMR-derived milks as a consequence of differences in fatty acid concentrations (O'Callaghan et al., 2016b). Significantly higher hardness scores at room temperature were reported for the TMR-derived butters compared to the pasture-derived butters which were attributed to the higher SFA content (which approached significance) and the significantly higher concentrations of palmitic acid in the TMR-derived butters. Onset of crystallisation for TMR butters also occurred at significantly higher temperatures, a factor which would contribute to increased hardness at room temperature. Volatile analysis revealed significant differences between butters, and toluene was higher in pasture-based products and was identified as a differentiating flavour compound. In terms of sensory analysis, the butter manufactured from grass-derived milk scored the highest in terms of appearance, flavour and colour. Similarly, the TMR-derived cheeses exhibited increased hardness compared to the pasture-derived cheeses at room temperature which was attributed to the significantly higher concentration of palmitic acid in the TMR milk.

The results indicate that pasture-based milk contains significantly higher concentrations of fat, protein and casein than milk produced from cows fed TMR diets indoors, and in particular, milk from pasture-fed cows (grass with or without white clover) has significantly higher concentrations of healthy fatty acids. Such data provide scientific substantiation for dairy produce from pasture-fed animals as superior, from a compositional and nutritional perspective, to that derived from their indoor counterparts. However, the long-term benefits of pasture-based produce on human health remain to be confirmed through human clinical studies.

\section{Variation within pasture-based systems}

Seasonal variation in grass growth has been shown to significantly influence the fatty acid composition of milk (Riel,
1963; Parodi, 1977; Stanton et al., 1997). For example, the CLA content of milk fat has been reported to range from $\sim 2$ to $30 \mathrm{mg} / \mathrm{g}$ fat (Riel, 1963; Stanton et al., 1997), with much of the variation being attributed to seasonal influences on pasture quality. High CLA contents were reported in milk from cows fed on pasture in spring (April and May, 6.8 mg CLA/g fat) and low levels were reported in midsummer and winter ( 4.3 $\mathrm{mg} \mathrm{CLA} / \mathrm{g}$ fat) (Kim et al., 2009). There are seasonal variations in the $n-3$ content of milk with higher levels reported in summer and lower in winter. A recent meta-analysis of organic compared with conventional milk reported higher $n-3$ PUFA and CLA in organic milk and these milk composition parameters showed strong positive associations with grazing intake. In contrast, there were positive associations between concentrate, maize silage, hay and straw intake and SFA content (Średnicka-Tober et al., 2016). Cullinane et al. (1984) showed a seasonal variation in the fatty acid composition of Irish butter including variations in the levels of butyric acid and C18-unsaturated fatty acids.

\section{Impact of different feeding systems on human health: milk}

Studies investigating the differential effects of milk products produced from different diets and management systems on human health are scarce and those which have been conducted have generated mixed results. In a randomised controlled study, Werner et al. (2013) investigated the impact of consuming butter derived from mountain pasture-grazing cows compared to consumption of conventional Danish butter on risk markers of metabolic syndrome in a 12-wk study involving 68 healthy subjects. As there were no differences in blood lipids and inflammation between groups at the end of the study, the authors concluded that mountain pasturederived dairy products were not healthier than those derived from high-input conventional systems despite the fact that cholesterol-raising SFAs were reduced by $20 \%$ in the butter derived from pasture-fed cows group. Consumption of butter naturally enriched with ruminant trans fatty acids, of which vaccenic acid was the predominant isomer and equivalent to $\sim 1 \%$ of daily energy, did not significantly impact low-density lipoprotein (LDL) cholesterol levels in 61 healthy women following a 4-wk study (Lacroix et al., 2012). The butter naturally enriched with vaccenic acid was produced from selected cows fed concentrates, alfalfa and corn (Z. mays) silage, with the addition of corn oil. In contrast, consumption of butter with a naturally higher content of vaccenic acid and MUFAs did reduce total cholesterol and plasma high-density lipoprotein (HDL) cholesterol concentrations in healthy young men in a double-blind, randomised 5-wk parallel intervention study, compared to the consumption of control butter with 
higher amounts of SFAs (Tholstrup et al., 2006). Consumption of dairy products naturally enriched with CLA from pasturefed cattle for $56 \mathrm{~d}$ did not significantly alter selected health risk factors (insulin sensitivity, body composition, circulating lipids as well as other disease risk factors) in healthy women when compared to consumption of dairy products with threefold less CLA, derived from grain-fed cattle (Brown et al., 2011). Livingstone et al. (2012) reviewed nine long-term human intervention studies that used modified dairy products (modified via cows' diet) to determine the effects on CVD risk markers where the majority of studies used modified butter and assessed changes in blood cholesterol as the main risk marker. Overall, the results suggest that modified dairy products may be beneficial to CVD risk in healthy and hypercholesterolaemic individuals; however, current evidence is insufficient and further studies are warranted.

\section{Nutritional quality of bovine meat}

Red meat is an important source of dietary protein for many people being a source of all the essential amino acids. Beef, in particular, is also a source of B vitamins and minerals including zinc and iron; indeed, it contains 2.5 times more iron than pork and 5 times more iron than poultry (Micinski et al., 2012). Interestingly, the European Environment Agency reported that consumption of bovine meat in the European Union (EU) decreased by nearly $14 \%$ between 2000 and 2013 , coinciding with increased consumption of cheese and poultry meat (European Environment Agency, 2017). This reduction in consumption of bovine meat stems from associations between red meat, its SFA content and risk of CVD and cancer. Of note, beef has a higher proportion of the SFA stearic acid (C18:0) compared to other meats, which is regarded as being neutral in terms of raising blood cholesterol (Grundy, 1994; EFSA, 2010; Vargas-Bello-Pérez \& Larraín, 2017). The link between beef intake and health risk is not the only reason for reduced consumption. Some EU countries reported a decline in beef consumption due to the correlation with outbreak of diseases such the bovine spongiform encephalopathy (Pires et al., 2009). In this regard, correct consumer information related to health risks and safety is very important. Another significant factor in the reduction of meat consumption is the impact of animal-derived foods on the environment. Studies have shown that reducing meat consumption could ease landuse pressures (Stehfest et al., 2009; Tilman \& Clark, 2014) and reduce greenhouse gas (GHG) emissions (Stehfest et al., 2009; Popp et al., 2010; Hedenus et al., 2014; Tilman \& Clark, 2014). Springmann et al. (2016) estimated that transitioning to more plant-based diets that are in line with standard dietary guidelines could reduce GHG emissions by $29-70 \%$ compared with a reference scenario in 2050. In addition, such a dietary change could also reduce global mortality by $6-10 \%$ (Springmann et al., 2016).

Fat in meat occurs in the form of glycerol esters, cholesterol, phospholipids and fatty acid esters deposited in intramuscular, intermuscular and subcutaneous adipose stores (Scollan et al., 2017). The intramuscular fat of beef varies between 20 and 50 $\mathrm{g} / \mathrm{kg}$ and contains $450-480 \mathrm{mg} / 100 \mathrm{~g}$ of SFAs, $350-450 \mathrm{mg} / 100$ $\mathrm{g}$ of MUFAs and up to $50 \mathrm{~g} / 100 \mathrm{~g}$ of PUFAs (Bessa et al., 2015; Clonan et al., 2016). The ratio of $n-6$ to n-3 PUFA in ruminant meat is generally $<3.0$, but in animals fed high amounts of cereal grains it has been reported to exceed 5.5 (Scollan et al., 2006; Sinclair, 2007). Beef is also a source of CLA and trans fats, the proportions of which vary depending on the breed and production system. Conjugated linoleic acid in retail beef has been reported to vary between 340 and $820 \mathrm{mg} / 100 \mathrm{~g}$ of total fatty acids (Kraft et al., 2008; Aldai et al., 2009, 2010).

A number of studies have investigated the association between meat consumption and mortality or disease risk. The NIHAARP Diet and Health Study investigated the link between meat intake and mortality with a cohort of 500,000 people aged 50-71 years and concluded that intakes of red meat and processed meat were associated with modest increases in total mortality, cancer mortality and CVD mortality (Sinha et al., 2009). This finding has been corroborated by other studies (Pan et al., 2012; Schwingshackl et al., 2017). A systematic review and meta-analysis of 111 cohort studies to quantify the dose response between food and beverage intake and colorectal cancer risk reported that colorectal cancer risk increases by $12 \%$ for each $100 \mathrm{~g} / \mathrm{d}$ increase in red and processed meat intake, while the risk decreases by $13 \%$ for each 400 $\mathrm{g} / \mathrm{d}$ increase of dairy product intake (Vieira et al., 2017). In a prospective cohort study of 51,683 Japanese people aged 40-79 years, Nagao et al. (2012) concluded that moderate meat consumption (up to $\sim 100 \mathrm{~g} / \mathrm{d}$ ) was not associated with increased mortality from ischemic heart disease, stroke or total CVD. More recently, a meta-analysis of 24 randomised clinical trials revealed that consumption of $\geq 0.5$ servings of total red meat/d does not impact blood lipids and lipoproteins or blood pressure (O'Connor et al., 2017). But as VargasBello-Pérez and Larraín (2017) point out, there is no single definition of which meats are included in the term "red meats" and most often it includes pork, beef and lamb and in some studies, processed meat as well. In this regard, in a systematic review and meta-analysis of the evidence, Micha et al. (2010) concluded that consumption of processed meats, but not red meats, was associated with a higher incidence of $\mathrm{CHD}$ and diabetes mellitus. Given that modern evidence now questions the link between dietary SFA intake and CVD risk, it appears that compounds such as heme iron and sodium, in addition to other preservatives, may in fact contribute to the negative cardiovascular effects of certain meats (Mozaffarian, 2016). Known/suspected carcinogenic compounds may appear in 
processed meat as a result of certain processing procedures such as curing or smoking (Domingo \& Nadal, 2017). In addition, the microbial metabolite trimethylamine- $\mathrm{N}$-oxide (TMAO), derived from dietary choline, lecithin and carnitine, has been identified as a risk factor for CVD (Wang et al., 2011). These three nutrients are found in red meat (Velasquez et al., 2016) and research has confirmed TMAO production from carnitine in humans by the gut microbiota (Koeth et al., 2013). This suggests that gut microbial-derived production of TMAO could be a link between red meat and CVD risk.

Meat product quality from a pasture-based feeding system

In the same way that ruminant animal feeding regimen alters the fatty acid profiles of milk, the fatty acid profiles of ruminant meats can also be adjusted through diet, enabling the production of healthier meat with decreased SFA contents and increased MUFAs and PUFAs. Pasture-based diets have been shown to increase CLA and vaccenic acid $(C 18: 1, t 11)$ content of beef, to increase the cholesterol-neutral fatty acid, stearic acid (C18:0), and to reduce cholesterol-associated fatty acids including myristic (C14:0) and palmitic (C16:0) acids (Daley et al., 2010). In addition, pasture feeding has been associated with increased $\beta$-carotene content in beef (Descalzo et al., 2005), as well as increased vitamin $E$ and antioxidant capacity (Realini et al., 2004; De la Fuente et al., 2009) compared to grain-fed animals. For example, the intramuscular fatty acid composition of beef was significantly improved by including pasture in the diet (French et al., 2000). Indeed, increasing pasture intake and decreasing the proportion of concentrates resulted in a significant linear decrease in SFA concentration and in the n-6:n-3 PUFA ratio and significantly increased CLA concentration. Meat derived from steers reared and finished on pasture had higher concentrations of $n-3$ fatty acids, lower $\mathrm{n}-6: \mathrm{n}-3$ PUFA ratios as well as higher magnesium and lower potassium contents compared to meat from steers finished on concentrates (de Freitas et al., 2014). The type of pasture may also impact the fatty acid profiles of meat. For example, sheep grazed on rangeland pasture (grasses and native shrubs) had higher percentages of $n-6$ and $n-3$ PUFAs compared with sheep fed on naturalised grassland (Ramírez-Retamal et al., 2014). However, the meat of lambs grazing on different dryland forages in Chile showed no significant differences in fatty acid profiles (Gallardo et al., 2011). Despite this, Whittington et al. (2006) reported that meat from lambs grazed on heather (dominant species: Calluna vulgaris, Vaccinium myrtillus and Deschampsia flexuosa) and mooreland (dominant species: Festuca ovina, D. flexuosa, Nardus stricta) had significantly higher n-6, C22:6 and n-3 PUFAs compared to sheep grazed on perennial ryegass.
Such differences can be linked to lipids in the herbage itself as well as plant factors which influence endogenous lipolysis and biohydrogenation in the rumen, for instance, tannins and polyphenol oxidase, as examples (Buccioni et al., 2012; Toral et al., 2018).

In a review of the literature examining the impact of forage feeding versus grain finishing on beef nutrients in the United States, Van Elswyk \& McNeill (2014) concluded that "beef cuts from cattle consuming mostly forage appear to be lower in fat than those from grain-finished beef, largely at the expense of MUFA". However, the study by Van Elswyk \& McNeill (2014) also highlighted issues associated with sensory quality as changing the fatty acid content of beef can influence colour, flavour, sensory attributes and shelf-life (Scollan et al., 2006). Steaks from pasture have been reported to be less tender than steaks from grain-finished beef (Blanco et al., 2017). In addition, the external fat of pasture-derived beef has been reported to be more yellow (a consequence of increased $\beta$-carotene in adipose tissue). While flavour acceptability varies in terms of individual preference and cultural norms, trained sensory panellists reported that beef from pasture-finished cattle lacked beef flavour and presented greater off-flavours than beef from grain-finished cattle (Duckett et al., 2013). Interestingly, a study investigating health information impact on the relative importance of beef attributes including its enrichment with PUFA and CLA on Spanish consumers revealed that informed consumers are willing to accept meat with a higher amount of visible fat once it is enriched with beneficial fatty acids (Kallas et al., 2014) and a follow-on study revealed that informing consumers about beneficial fatty acids would favour marketing of beef enriched in n-3 PUFA through animal diet (Baba et al., 2016).

\section{Impact of different feeding systems on human health: meat}

Human intervention studies investigating the impact of beef as a result of the animal feeding system on human health are limited. A crossover dietary intervention involving 27 normocholesterolaemic men investigated the effect of consuming $114 \mathrm{~g}$ ground beef patties/wk for $5 \mathrm{wk}$ derived from pasture-fed cattle (low MUFA) or grain-fed cattle (high MUFA) on cholesterol (Gilmore et al., 2011). It was reported that both beef interventions decreased $\mathrm{HDL}(2)$ and $\mathrm{HDL}(3)$ particle diameters and increased plasma C18:0 and C20:4 (n-6) PUFA relative to baseline. The high MUFA ground beef intervention derived from grain-fed cattle significantly increased HDL cholesterol from baseline. Ten mildly hypercholesterolaemic men consumed hamburger patties derived from pasture-fed cattle (MUFA:SFA = 0.95; high SFA) for $5 \mathrm{wk}$ and following a 3-wk washout period consumed hamburger patties from grain-fed cattle (MUFA:SFA = 1.31; high MUFA) for another 5 wk (Adams et al., 2010). 
Following consumption of the high SFA hamburger, plasma triacylglycerols and the LDL:HDL ratio were significantly greater than after the high MUFA hamburger phase. Conversely, HDL cholesterol was greater after the high MUFA hamburger phase than after the high SFA hamburger phase.

While these studies used meat derived from pasture- or grain-fed cattle, each was a mixture of fat and lean trims. Thus, studies are required which examine the impact of lean trims only from different feeding systems on human health parameters. However, the studies presented suggest that different animal feeding systems may impact blood cholesterol profiles of meat consumers.

\section{Conclusion}

The nutritional composition, especially lipid profile and micronutrient (vitamin) composition of dairy and beef products, can be modified through the animal's diet resulting in products which may be nutritionally more beneficial in terms of human health. The lipid composition of milk and meat, in particular, is amenable to significant alterations generating fatty acid profiles which are more favourable towards a healthy lifestyle. In terms of dairy products, a limited number of studies have indicated the advantages of pasture-feeding regimens over other feeding systems resulting in milk and milk-derived products with increased PUFAs and CLA and reduced SFAs. The resulting products can also differ in terms of their technological properties as we have seen with butter and can differ in terms of texture and taste.

There is a severe paucity of studies investigating the influence of meat from different feeding systems on human health and thus it is difficult to generate a conclusion.

Overall, further studies investigating the impact of pasturederived dairy and meat products versus their grain-derived counterparts on human health are required. In addition, educating consumers on the role of the different fatty acids in promoting good health and on the levels of these fatty acids in food products is essential, enabling consumers to make informed decisions when choosing meat and dairy products as part of their daily diet. However, further research on the nutritional aspects of pasture-fed animals is envisaged, in line with the increasing consumer awareness that natural animal feeding correlates with animal and human health and the consumer desire for natural products, including animalderived ones (Gaggia et al., 2011; Bolger et al., 2017).

\section{References}

Adams, T.H., Walzem, R.L., Smith, D.R., Tseng, S. and Smith, S.B. 2010. Hamburger high in total, saturated and trans-fatty acids decreases HDL cholesterol and LDL particle diameter, and increases TAG, in mildly hypercholesterolaemic men. British Journal of Nutrition 103: 91-98.

Aldai, N., Dugan, M.E.R., Rolland, D.C. and Kramer, J.K.G. 2009. Survey of the fatty acid composition of Canadian beef: backfat and longissimus lumborum muscle. Canadian Journal of Animal Science 89: 315-329.

Aldai, N., Dugan, M.E.R. and Kramer, J.K.G. 2010. Can the trans-18:1 and conjugated linoleic acid profiles in retail ground beef be healthier than steak? Journal of Food Composition and Analysis 23: 326-332.

Baba, Y., Kallas, Z., Costa-Font, M., Gil, J.M. and Realini, C.E. 2016. Impact of hedonic evaluation on consumers' preferences for beef attributes including its enrichment with n-3 and CLA fatty acids. Meat Science 111: 9-17.

Banks, W. and Christie, W.W. 1990. Feeding cows for the production of butter with good spreadability at refrigeration temperatures. Outlook on Agriculture 19: 43-47.

Barłowska, J., Szwajkowska, M., Litwińczuk, Z. and Król, J. 2011. Nutritional value and technological suitability of milk from various animal species used for dairy production. Comprehensive Reviews in Food Science and Technology 10: 291-302.

Bessa, R.J.B., Alves, S.P. and Santos-Silva, J. 2015. Constraints and potentials for the nutritional modulation of the fatty acid composition of ruminant meat. European Journal of Lipid Science and Technology 117: 1325-1344.

Blanco, M., Casasus, I., Ripoll, G., Alberti, P., Panea, B. and Joy, M. 2017. Is meat quality of forage-fed steers comparable to the meat quality of conventional beef from concentrate-fed bulls. Journal of the Science of Food and Agriculture 97: 4943-4952.

Bolger, Z., Brunton, N.P., Lyng, J.G. and Monahan, F.J. 2017. Comminuted meat products - consumption, composition, and approaches to healthier formulations. Food Reviews International 33: 143-166.

Brown, A.W., Trenkle, A.H. and Beitz, D.C. 2011. Diets high in conjugated linoleic acid from pasture-fed cattle did not alter markers of health in young women. Nutrition Research 31: 33-41.

Buccioni, A., Decandia, M., Minieri, S., Molle, G. and Cabiddu, A. 2012. Lipid metabolism in the rumen: new insights on lipolysis and biohydrogenation with an emphasis on the role of endogenous plant factors. Animal Feed Science and Technology 174: 1-25.

Cashman, K.D. 2006. Milk minerals (including trace minerals) and bone health. International Dairy Journal 16: 1389-1398.

Clonan, A., Roberts, K.E. and Holdsworth, M. 2016. Socioeconomic and demographic drivers of red and processed meat consumption: implications for health and environmental sustainability. Proceedings of the Nutrition Society 75: 367-373.

Connor, W.E. 2000. Importance of n-3 fatty acids in health and disease. American Journal of Clinical Nutrition 71: 171S-175S.

Couvreur, S., Hurtaud, C., Lopez, C., Delaby, L. and Peyraud, J.-L. 2006. The linear relationship between the proportion of fresh grass 
in the cow diet, milk fatty acid composition, and butter properties. Journal of Dairy Science 89: 1956-1969.

Cullinane, N., Aherne, S., Connolly, J.F. and Phelan, J.A. 1984. Seasonal variation in the triglyceride and fatty acid composition of Irish butter. Irish Journal of Food Science and Technology 8: 1-12.

Daley, C.A., Abbott, A., Doyle, P.S., Nader, G.A. and Larson, S. 2010. A review of fatty acid profiles and antioxidant content in grass-fed and grain-fed beef. Nutrition Journal 9: 10.

de Freitas, A.K., Lobato, J.F.P., Cardoso, L.L., Tarouco, J.U., Vieira, R.M., Dillenburg, D.R. and Castro, I. 2014. Nutritional composition of the meat of Hereford and Braford steers finished on pastures or in a feedlot in southern Brazil. Meat Science 96: 353-360.

De la Fuente, J., Diaz, M.T., Alvarez, I., Oliver, M.A., Font, I., Furnols, M., Sanudo, C., Campo, M.M., Montossi, F., Nute, G.R. and Caneque, V. 2009. Fatty acid and vitamin E composition of intramuscular fat in cattle reared in different production systems. Meat Science 82: 331-337.

Deng, Y., Misselwitz, B., Dai, N. and Fox, M. 2015. Lactose intolerance in adults: biological mechanism and dietary management. Nutrients 7: 8020-8035.

Descalzo, A.M., Insani, E.M., Biolatto, A., Sancho, A.M., Garcia, P.T., Pensel, N.A. and Josifovich, J.A. 2005. Influence of pasture or grainbased diets supplemented with vitamin $\mathrm{E}$ on antioxidant/oxidative balance of Argentine beef. Journal of Meat Science 70: 35-44.

Domingo, J.L. and Nadal, M. 2017. Carcinogenicity of consumption of red meat and processed meat: a review of the scientific news since the IARC decision. Food and Chemical Toxicology 105: 256-261.

Douëllou, T., Montel, M.C. and Thevenot Sergentet, D. 2017. Invited review: Anti-adhesive properties of bovine oligosaccharides and bovine milk fat globule membrane-associated glycoconjugates against bacterial food enteropathogens. Journal of Dairy Science 100: 3348-3359.

Duckett, S.K., Neel, J.P.S., Lewis, R.M., Fontenot, J.P. and Clapham, W.M. 2013. Effects of forage species or concentrate finishing on animal performance, carcass and meat quality. Journal of Animal Science 91: 1454-1467.

Dupertuis, Y.M., Meguid, M.M. and Pichard, C. 2007. Colon cancer therapy: new perspectives of nutritional manipulations using polyunsaturated fatty acids. Current Opinion in Clinical Nutrition and Metabolic Care 10: 427-432.

Duplessis, M., Pellerin, D., Cue, R.I. and Girard, C.L. 2016. Short communication: Factors affecting vitamin B12 concentration in milk of commercial dairy herds: an exploratory study. Journal of Dairy Science 99: 4886-4892.

Edwards, C.W. and Younus, M.A. 2019. Cow milk allergy. StatsPearl. Available online: https://www.ncbi.nlm.nih.gov/books/NBK542243/ [Accessed 24 September 2019].

EFSA. 2010. Scientific opinion on the substantiation of health claims related to stearic acid and maintenance of normal blood cholesterol concentrations (ID 716, 1657) pursuant to Article 13(1) of Regulation (EC) No 1924/2006. EFSA Journal 8: 1476.
European Environment Agency. 2017. Food consumption - animal based protein. Available online: https://www.eea.europa.eu/ airs/2018/resource-efficiency-and-low-carbon-economy/foodconsumption-animal-based [Accessed 24 September 2019].

French, P., Stanton, C., Lawless, F., O'Riordan, G., Monahan, F.J., Caffrey, P.J. and Moloney, A.P. 2000. Fatty acid composition, including conjugated linoleic acid, of intramuscular fat from steers offered grazed grass, grass silage, or concentrate-based diets. Journal of Animal Science 78: 2849-2855.

Food and Agriculture Organization of the United Nations (FAO). 2013. Dietary Protein Quality Evaluation in Human Nutrition: Report of an FAO Expert Consultation. Rome. FAO Food and Nutrition Paper 92: 1-66.

Gaggia, F., Di Gioia, D., Baffoni, L. and Biavati, B. 2011. The role of protective and probiotic cultures in food and feed and their impact in food safety. Trends in Food Science \& Technology 22: S58-S66.

Gallardo, M., Pulido, R. and Gallo, C. 2011. Fatty acid composition of longissimus dorsi muscle of Suffolk down lambs fed on different dryland forages. Chilean Journal of Agricultural Research 71: 566-571.

Gilmore, L.A., Walzem, R.L., Crouse, S.E., Smith, D.R., Adams, T.H., Vaidyanathan, V., Cao, X. and Smith, S.B. 2011. Consumption of high-oleic acid ground beef increases HDL-cholesterol concentration but both high- and low-oleic acid ground beef decrease HDL particle diameter in normocholesterolemic men. Journal of Nutrition 141: 1188-1194.

Grundy, S.M. 1994. Influence of stearic acid on cholesterol metabolism relative to other long-chain fatty acids. American Journal of Clinical Nutrition 60: 986S-990S.

German, J.B. 1999. Butyric acid: a role in cancer prevention. Nutrition Bulletin 24: 203-209.

Haug, A., Høstmark, A.T. and Harstad, O.M. 2007. Bovine milk in human nutrition-a review. Lipids in Health and Disease 6: 25.

Hedenus, F, Wirsenius, S. and Johansson, D.J.A. 2014. The importance of reduced meat and dairy consumption for meeting stringent climate change targets. Climate Change 124: 79-91.

Hurtaud, C. and Peyraud, J. 2007. Effects of feeding camelina (seeds or meal) on milk fatty acid composition and butter spreadability. Journal of Dairy Science 90: 5134-5145.

Jensen, R.G. 2002. The composition of bovine milk lipids: January 1995 to December 2000. Journal of Dairy Science 85: 295-350.

Kallas, Z., Realini, C.E. and Gil, J.M. 2014. Health information impact on the relative importance of beef attributes including its enrichment with polyunsaturated fatty acids (omega- 3 and conjugated linoleic acid). Meat Science 97: 497-503.

Kepler, C.R., Hirons, K.P., McNeill, J.J. and Tove, S.B. 1966. Intermediates and products of the biohydrogenation of linoleic acid by Butyrivibrio Fibrisolvens. Journal of Biological Chemistry 241: 1350-1354.

Kim, J.H., Kwon, O.J., Choi, N.J., Oh, S.J., Jeong, H.Y., Song, M.K., Jeong, I. and Kim, Y.J. 2009. Variations in conjugated linoleic acid 
(CLA) content of processed cheese by lactation time, feeding regimen, and ripening. Journal of Agricultural and Food Chemistry 57: 3235-3239.

Koeth, R.A., Wang, Z., Levison, B.S., Buffa, J.A., Org, E., Sheehy, B.T., Britt, E.B., Fu, X., Wu, Y., Li, L., Smith, J.D., DiDonato, J.A., Chen, J., Li, H., Wu, G.D., Lewis, J.D., Warrier, M., Brown, J.M., Krauss, R.M., Wilson Tang, W.H., Bushman, F.D., Lusis, A.J. and Hazen, S.L. 2013. Intestinal microbiota metabolism of L-carnitine, a nutrient in red meat, promotes atherosclerosis. Nature Medicine 19: $576-585$.

Kraft, J., Kramer, J.K.G., Schoene, F., Chambers, J.R. and Jahreis, G. 2008. Extensive analysis of long-chain polyunsaturated fatty acids, CLA, trans-18:1 isomers, and plasmalogenic lipids in different retail beef types. Journal of Agricultural and Food Chemistry 56: 4775-4782.

Lacroix, E., Charest, A., Cyr, A., Baril-Gravel, L., Lebeuf, Y., Paquin, P., Chouinard, P.Y., Coutere, P. and Lamarche, B. 2012. Randomized controlled study of the effect of a butter naturally enriched in trans fatty acids on blood lipids in healthy women. American Journal of Clinical Nutrition 95: 318-325.

Lindmark Månsson, H., 2008. Fatty acids in bovine milk fat. Food and Nutrition Research 52: 1.

Livingstone, K.M., Lovegrovem, J.A. and Givens, D.I. 2012. The impact of substituting SFA in dairy products with MUFA or PUFA on CVD risk: evidence from human intervention studies. Nutrition Research Reviews 25: 193-206.

Mann, N.J., Ponnampalam, E.N., Yep, Y. and Sinclair, A.J. 2003. Feeding regimes affect fatty acid composition in Australian beef cattle. Asia Pacific Journal of Clinical Nutrition 12: S38.

Marinangeli, C.P.F. and House, J.D. 2017. Potential impact of the digestible indispensable amino acid score as a measure of protein quality on dietary regulations and health. Nutrition Reviews 75: 658-667.

McAuliffe, G.A., Takahashi, T. and Lee, M.R.F. 2018. Framework for life cycle assessment of livestock production systems to account for the nutritional quality of final products. Food and Energy Security 7: e00143.

Micha, R., Wallace, S.K. and Mozaffarian, D. 2010. Red and processed meat consumption and risk of incident coronary heart disease, stroke, and diabetes mellitus. Circulation 121: 2271-2283.

Micinski, J., Zwierchowski, G., Kowalski, I.M., Wojtkiewicz, J. and Szarek, J. 2012. Health-supporting properties of beef. Journal of Elementology 17: 149-157.

Milani, A., Basirnejad, M., Shahbazi, S. and Bolhassani, A. 2017. Carotenoids: biochemistry, pharmacology and treatment. British Journal of Pharmacology 174: 1290-1324.

Mills, S, Ross, R.P., Hill, C., Fitzgerald, G.F. and Stanton, C. 2011. Milk intelligence: mining milk for bioactive substances associated with human health. International Dairy Journal 21: 377-401.

Molendi-Coste, O., Legry, V. and Leclercq, I.A. 2011. Why and how meet N-3 PUFA dietary recommendations? Gastroenterology Research and Practice 2011: 1-11.
Mozaffarian, D. 2016. Dietary and policy priorities for cardiovascular disease, diabetes, and obesity - a comprehensive review. Circulation 133: 187-225.

Nagao, M., Iso, H., Yamagishi, K., Date, C. and Tamakoshi, A. 2012. Meat consumption in relation to mortality from cardiovascular disease among Japanese men and women. European Journal of Clinical Nutrition 66: 687-693.

O'Callaghan, T.F., Hennessy, D., McAuliffe, S., Kilcawley, K.N., O'Donovan, M., Dillon, P., Ross, R.P. and Stanton, C. 2016a. Effect of pasture versus indoor feeding systems on raw milk composition and quality over an entire lactation. Journal of Dairy Science 99: 9424-9440.

O'Callaghan, T.F., Faulkner, H., McAuliffe, S., O'Sullivan, M.G., Hennessy, D., Dillon, P., Kilcawley, K.N., Stanton, C. and Ross, R.P. 2016b. Quality characteristics, chemical composition, and sensory properties of butter from cows on pasture versus indoor feeding systems. Journal of Dairy Science 99: 9441-9460.

O'Callaghan, T.F., Mannion, D.T., Hennessy, D., McAuliffe, S., O'Sullivan, M.G., Leeuwendaal, N., Beresford, T.P., Dillon, P., Kilcawley, K.N., Sheehan, J.J., Ross, R.P. and Stanton, C. 2017. Effect of pasture versus indoor feeding systems on quality characteristics, nutritional composition and sensory and volatile properties of full-fat Cheddar cheese. Journal of Dairy Science 100: 6053-6073.

O'Connor, L.E., Kim, J.E. and Campbell, W.W. 2017. Total red meat intake of $\geq 0.5$ servings/d does not negatively influence cardiovascular disease risk factors: a systemically searched meta-analysis of randomized controlled trials. American Journal of Clinical Nutrition 105: 57-69.

Pan, A., Sun, Q., Bernstein, A.M., Schulze, M.B., Manson, J.E., Stampfer, M.J., Willett, W.C. and Hu, F.B. 2012. Red meat consumption and mortality: results from 2 prospective cohort studies. Archives of Internal Medicine 172: 555-563.

Parodi, P.W. 1977. Conjugated octadecadienoic acids of milk fat. Journal of Dairy Science 60: 1550-1553.

Petrone, G., Conte, M.P., Longhi, C., di Santo, S., Superti, F., Ammendolia, M.G., Valenti, P. and Seganti, L. 1998. Natural milk fatty acids affect survival and invasiveness of Listeria monocytogenes. Letters in Applied Microbiology 27: 362-368.

Pires, S.M., Evers, E.G., van Pelt, W., Ayers, T., Scallan, E., Angulo, F.J., Havelaar, A., Hald, T. and Med-Vet-Workpackage 28 Working Group. 2009. Attributing the human disease burden of foodborne infections to specific sources. Foodborne Pathogens and Disease 6: 417-424.

Popp, A., Lotze-Campen, H. and Bodirsky, B. 2010. Food consumption, diet shifts and associated non- $\mathrm{CO}_{2}$ greenhouse gases from agricultural production. Global Environmental Change 20: $451-462$.

Poulsen, R.C., Moughan, P.J. and Kruger, M.C. 2007. Longchain polyunsaturated fatty acids and the regulation of bone metabolism. Experimental Biology and Medicine (Maywood) 232: 1275-1288. 
Qin, L.Q., Xy, J.Y., Han, S.F., Zhang, Z.L., Zhao, Y.Y. and Szeto, I.M. 2015. Dairy consumption and rise of cardiovascular disease: an updated meta-analysis of prospective cohort studies. Asia Pacific Journal of Clinical Nutrition 24: 90-100.

Ramírez-Retamal, J., Morales, R., Martinez, M.E. and de la Barra, R. 2014. Effect of type of pasture on the meat characteristics of Chilote lambs. Food and Nutrition Sciences 5: 635-644.

Realini, C.E., Duckett, S.K., Brito, G.W., Rizza, M.D. and De Mattos, D. 2004. Effect of pasture vs. concentrate feeding with or without antioxidants on carcass characteristics, fatty acid composition, and quality of Uruguayan beef. Meat Science 66: 567-577.

Riel, R.R. 1963. Physico-chemical characteristics of Canadian milk fat. Unsaturated fatty acids. Journal of Dairy Science 46: 102-106.

Rosqvist, F., Smedman, A., Lindmark-Mansson, H., Paulsson, M., Petrus, P., Straniero, S., Rudling, M., Dahlman, I. and Riserus, U. 2015. Potential role of milk fat globule membrane in modulating plasma lipoproteins, gene expression, and cholesterol metabolism in humans: a randomized study. American Journal of Clinical Nutrition 102: 20-30.

Sanchez-Juanes, F., Alonso, J.M., Zancada, L. and Hueso, P. 2009. Glycosphingolipids from bovine milk and milk fat globule membranes: a comparative study. Adhesion to enterotoxigenic Escherichia coli strains. Biological Chemistry 390: 31-40.

Schaafsma, G. 2008. Lactose and lactose derivatives as bioactive ingredients in human nutrition. International Dairy Journal 18: 458-465.

Schwingshackl, L., Schwedhelm, C., Hoffmann, G., Lampousi, A.-M., Sven Knüppel, S., Iqbal, K., Bechthold, A., Schlesinger, S. and Boeing, H. 2017. Food groups and risk of all-cause mortality: a systematic review and meta-analysis of prospective studies. American Journal of Clinical Nutrition 105: 1462-1473.

Scollan, N., Hocquette, J.-F., Nuernberg, K., Dannenberger, D., Richardson, I. and Moloney, A. 2006. Innovations in beef production systems that enhance the nutritional and health value of beef lipids and their relationship with meat quality. Meat Science 74: 17-33.

Scollan, N.D., Price, E.M., Morgan, S.A., Huws, S.A. and Shingfield, K.J. 2017. Conference on 'The future of animal products in the human diet: health and environment concerns' Symposium 1: Meat, health and sustainability. Proceedings of the Nutrition Society 76: 603-618.

Séverin, S. and Wenshui, X. 2005. Milk biologically active components as neutraceuticals. Critical Reviews in Food Science and Nutrition 45: 645-656.

Siddiqui, R.A., Harvey, K.A. and Zaloga, G.P. 2008. Modulation of enzymatic activities by $n-3$ polyunsaturated fatty acids to support cardiovascular health. Journal of Nutritional Biochemistry 19: 417-437.

Sinclair, L.A. 2007. Nutritional manipulation of the fatty acid composition of sheep meat: a review. Journal of Agricultural Science 145: 419-434.
Sinha, R., Cross, A.J., Graubard, B.I., Leitzmann, M.F. and Schatzkin, A. 2009. Meat intake and mortality: a prospective study of over half a million people. Archives of Internal Medicine 169: 562-571.

Siri-Tarino, P.W., Sun, Q., Hu, F.B. and Krauss, R.M. 2010. Metaanalysis of prospective cohort studies evaluating the association of saturated fat with cardiovascular disease. The American Journal of Clinical Nutrition 91: 535-546.

Spitsberg, V.L. 2005. Bovine milk fat globule membrane as a potential neutraceutical. Journal of Dairy Science 88: 2289-2294.

Sprong, R.C., Hulstein, M.F. and Van der Meer, R. 2001. Bactericidal activities of milk lipids. Antimicrobial Agents and Chemotherapy 45: 1298-1301.

Sprong, R.C., Hulstein, M.F.E. and Van der Meer, R. 2002. Bovine milk fat components inhibit food-borne pathogens. International Dairy Journal 12: 209-215.

Springmann, M., Godfray, H.C.J., Rayner, M. and Scarborough, P. 2016. Analysis and valuation of the health and climate change cobenefits of dietary change. Proceedings of the National Academy of Sciences of the United States of America 113: 4146-4151.

Średnicka-Tober, D., Barański, M., Seal, C.J., Sanderson, R., Benbrook, C., Steinshamn, H., Gromadzka-Ostrowska, J., Rembiałkowska, E., Skwarło-Sońta, K., Eyre, M., Cozzi, G., Larsen, M.K., Jordon, T., Niggli, U., Sakowski, T., Calder, P.C., Burdge, G.C., Sotiraki, S., Stefanakis, A., Stergiadis, S., Yolcu, H., Chatzidimitriou, E., Butler, G., Stewart, G. and Leifert, C. 2016. Higher PUFA and n-3 PUFA, conjugated linoleic acid, $\alpha$-tocopherol and iron, but lower iodine and selenium concentrations in organic milk: a systematic literature review and meta- and redundancy analyses. British Journal of Nutrition 115: 1043-1060.

Stanton, C., Lawless, F., Murphy, J.J. and Connolly, J.F. 1997. Conjugated linoleic acid - a marketing advantage for animal fats. In: "Animal Fats: BSE and After" (ed. K. Berger), P.J. Barnes and Associates, Bridgwater, UK, pages 27-41.

Stanton, C., Murphy, J., McGrath, E. and Devery, R. 2003. Animal feeding strategies for conjugated linoleic acid enrichment of milk. In: "Advances in Conjugated Linoleic Acid Research" (eds. J.L. Sebedio, W.W. Christie and R.O. Adlof), AOCS Press, Champaign, IL, USA, pages 123-145.

Stehfest, E., Bouwman, L., van Vuuren, D.P., den Elzen, M.G.J., Eickhout. B. and Kabat, P. 2009. Climate benefits of changing diet. Climate Change 95: 83-102.

Syvaoja, E.L., Piironen,V., Varo, P., Koivistoinen, P. and Salminen, K. 1985. Tocopherols and tocotrienols in Finnish foods: dairy products and eggs. Milchwissenschaft 40: 467-469.

Szilagyi, A. 2004. Redefining lactose as a conditional prebiotic. Canadian Journal of Gastroenterology and Hepatology 18: 163167.

Tholstrup, T., Raff, M., Basu, S., Nonboe, P., Sejrsen, K. and Straarup, E.M. 2006. Effects of butter high in ruminant trans and monounsaturated fatty acids on lipoproteins, incorporation of fatty acids into lipid classes, plasma C-reactive protein, oxidative 
stress, hemostatic variables, and insulin in healthy young men. American Journal of Clinical Nutrition 83: 237-243.

Tilman, D. and Clark, M. 2014. Global diets link environmental sustainability and human health. Nature 515: 518-522.

Toral, P.G., Monahan, F.J., Hervás, G., Frutos, P. and Moloney, A.P. 2018. Review: Modulating ruminal lipid metabolism to improve the fatty acid composition of meat and milk. Challenges and opportunities. Animal 12: s272-s281.

Van Elswyk, M.A. and McNeill, S.H. 2014. Impact of grass/forage feeding versus grain finishing on beef nutrients and sensory quality: the U.S. experience. Meat Science 96: 535-540.

Vargas-Bello-Pérez, E. and Larraín, R. 2017. Impacts of fat from ruminants' meat on cardiovascular health and possible strategies to alter its lipid composition. Journal of the Science of Food and Agriculture 97: 1969-1978.

Velasquez, M.T., Ramezani, A., Manal, A., Raj, D.S. and Vanholder, R. 2016. Trimethylamine N-oxide: the good, the bad and the unknown. Toxins 8: 326.

Verkerk, G. 2003. Pasture-based dairying: challenges and rewards for New Zealand producers. Theriogenology 59: 553-561.

Vieira, A.R., Abar, L., Chan, D.S.M., Vingeliene, S., Polemiti, E., Stevens, C., Greenwood, D. and Norat, T. 2017. Foods and beverages and colorectal cancer risk: a systematic review and meta-analysis of cohort studies, an update of the evidence of the WCRF-AICR Continuous Update Project. Annals of Oncology 28: 1788-1802.

Ward, R.E., German, J.B., Corredig, M. 2006. Composition, applications, fractionation, technological and nutritional significance of milk fat globule membrane material. In: "Advanced Dairy
Chemistry Volume 2 Lipids" (eds. P.F. Fox, P.L.H. McSweeney), Springer, Boston, MA. https://doi.org/10.1007/0-387-28813-9_6.

Wang, Z., Klipfell, E., Bennett, B.J., Koeth, R., Levison, B.S., DuGar, B., Feldstein, A.E., Britt, E.B., Fu, X., Chung, Y.M., Wu, Y., Schauer, P., Smith, J.D., Allayee, H., Wilson Tang, W.H., DiDonato, J.A., Lusis, A.J. and Hazen, S.L. 2011. Gut flora metabolism of phosphotidylcholine promotes cardiovascular disease. Nature 472: 57-63.

Werner, L.B., Hellgren, L.I., Raff, M., Jensen, S.K., Petersen, R.A., Drachmann, T. and Tholstrup, T. 2013. Effects of butter from mountain-pasture grazing cows on risk markers of the metabolic syndrome compared with conventional Danish butter: a randomized controlled study. Lipids in Health and Disease 12: 99. Whittington, F., Dunn, R., Nute, G., Richardson, R. and Wood, J. 2006. Effect of pasture type on lamb product quality. In: "9th Annual Langford Food Industry Conference, New Developments in Sheepmeat Quality, Bristol, 24-25 May". Proceedings of the British Society of Animal Science, pages 27-31.

Wolfe, R.R. 2015. Update on protein intake: importance of milk proteins for health status of the elderly. Nutrition Reviews 73: 41-47.

Wood, F.W., Murphy, M.F. and Dunkley, W.L. 1975. Influence of elevated polyunsaturated fatty acids on processing and physical properties of butter. Journal of Dairy Science 58: 839-845.

Yang, B., Chen, H., Stanton, C., Ross, R.P., Zhang, H., Chen, Y.Q. and Chen, W. 2017. Review of the roles of conjugated linoleic acid in health and disease. Journal of Functional Foods 15: 314-325.

Zamberlin, S. 2012. Mineral elements in milk and dairy products. Mljekarstvo 62: 111-125. 